\title{
Composition and Seasonal Variation of Brachyura and Anomura (Crustacea, Decapoda) Associated with Brown Mussel Farms at Praia da Cocanha, Brazil
}

\author{
Ligia Coletti Bernadochi, Fausto Silvestri and Alexander Turra* \\ Laboratório de Manejo; Ecologia e Conservação Marinha; Instituto Oceanográfico; Universidade de São Paulo; \\ Praça do Oceanográfico, 191; 05508-900; São Paulo - SP -Brasil
}

\begin{abstract}
The composition and seasonal variation of brachyuran and anomuran species associated with mussel farms were evaluated at Praia da Cocanha, São Paulo between May 2007 and February 2008. Nine mussel ropes were sampled at random in each quarter, and 1,208 organisms were identified, comprising five families and 28 species. The most numerous species was the porcellanid Pachycheles laevidactylus (18.5\%), followed by the xanthids Acantholobulus schmitti (16.6\%), Hexapanopeus paulensis (11.3\%), Panopeus americanus (10.2\%), and Menippe nodifrons (8.4\%). The exotic crab Charybdis hellerii was recorded throughout the study period. The ecological descriptors, except Pielou evenness index, varied significantly over the time. The highest abundance and diversity of the species were recorded during November and February. This pattern was reversed for Berger-Parker dominance, with the lowest values recorded in February. The development of epifauna was correlated with the different stages of the mussel farms, since the mean size of mussels and consequently the abundance of epibiotic organisms and the structural complexity on the mussel ropes increased from May (seeding) until February (harvest). Despite this, the temporal population variations in recruitment patterns of the different epibionts should not be overlooked. The results indicated that the mussel farms provided favorable conditions for the development of these crustacean groups, which could be used in environmental monitoring programs and / or be exploited for the aquarium trade.
\end{abstract}

Key words: Associated fauna, Mussel culture, Perna perna, Crustaceans, Community ecology

\section{INTRODUCTION}

In the sites with low hydrodynamics and conditions of constant immersion, mussel farms are a suitable secondary substrate for the colonization of epibionts, providing shelter and food for large numbers of associated organisms (Bayne 1976; Marenzi and Manzoni 1998; Vaquero 2006; Sá et al. 2007). Studies of the biodiversity and heterospecific associations of the organisms with shellfish farms are scarce, although of great importance because they provide a better understanding of biological phenomena and the role that each species performs in this system, contributing to livestock improvement and providing useful information for farm management in order to maximize productivity (Bayne 1976; Marenzi and Manzoni 1998; Vaquero 2006; Sá et al. 2007).

Previous studies cite decapods crustaceans as frequently associated with bivalve farms (Uribe et al. 2001; Carvalho 2007). The presence of crabs on the mussel ropes and structures such as buoys and strings may be related to increases in mortality of the reared mussels, especially of seeds (Freitas

*Author for correspondence: turra@usp.br 
1997). Moreover, the exploitation of these species, which are usually discarded during the handling of ropes and harvest of mussels, for the aquarium trade may represent an alternative source of income for shellfishermen.

The infra-order Brachyura, with over 300 species known on the Brazilian coast, is the most important among marine crustaceans (Melo 1999). Of these species, 188 occur on the Sao Paulo coast (Bertini et al. 2004). The estimated 117 species of the infra-order Anomura are distributed along the entire the Brazilian coast (Amaral and Jablonski 2005).

In other areas of the world, the presence of crabs in the fauna associated with mussel farms has also been reported (Romero et al. 1982; GonzálezGurriarán 1986; Freire and González-Gurriarán 1995; Mallet et al. 2009). Some studies reported on the reproductive biology of brachyurans (Muiño 2002) and anomurans (Sampedro et al. 1997) at farm sites, while other works focused on the description of vagile and/or sessile fauna associated with mussel ropes (Freitas 1997; Sá et al. 2007) and its impact on productivity (Metri et al. 2002; Leite 2007). However, there are no specific studies on seasonal variation in the composition of brachyurans and anomurans in mussel farms.

It is believed that the assemblages of brachyurans and anomurans can vary in different mussel-farm regions in Brazil and around the world, and these changes may occur according to the local environmental characteristics. The existence of temporal variation in faunal composition still needs to be described. Therefore, this study aimed to characterize the composition of the brachyuran and anomuran faunas associated with mussel ropes in Praia da Cocanha and to analyze their temporal variability.

\section{Study area}

Located in Caraguatatuba, the area of Praia da Cocanha (-23.5800 and -45.3200$)$ has the highest density of mussel farms on the coast of São Paulo State (Fig. 1). The study area consisted of 14 farms in two areas, totaling 11 hectares (Sinau 2009).

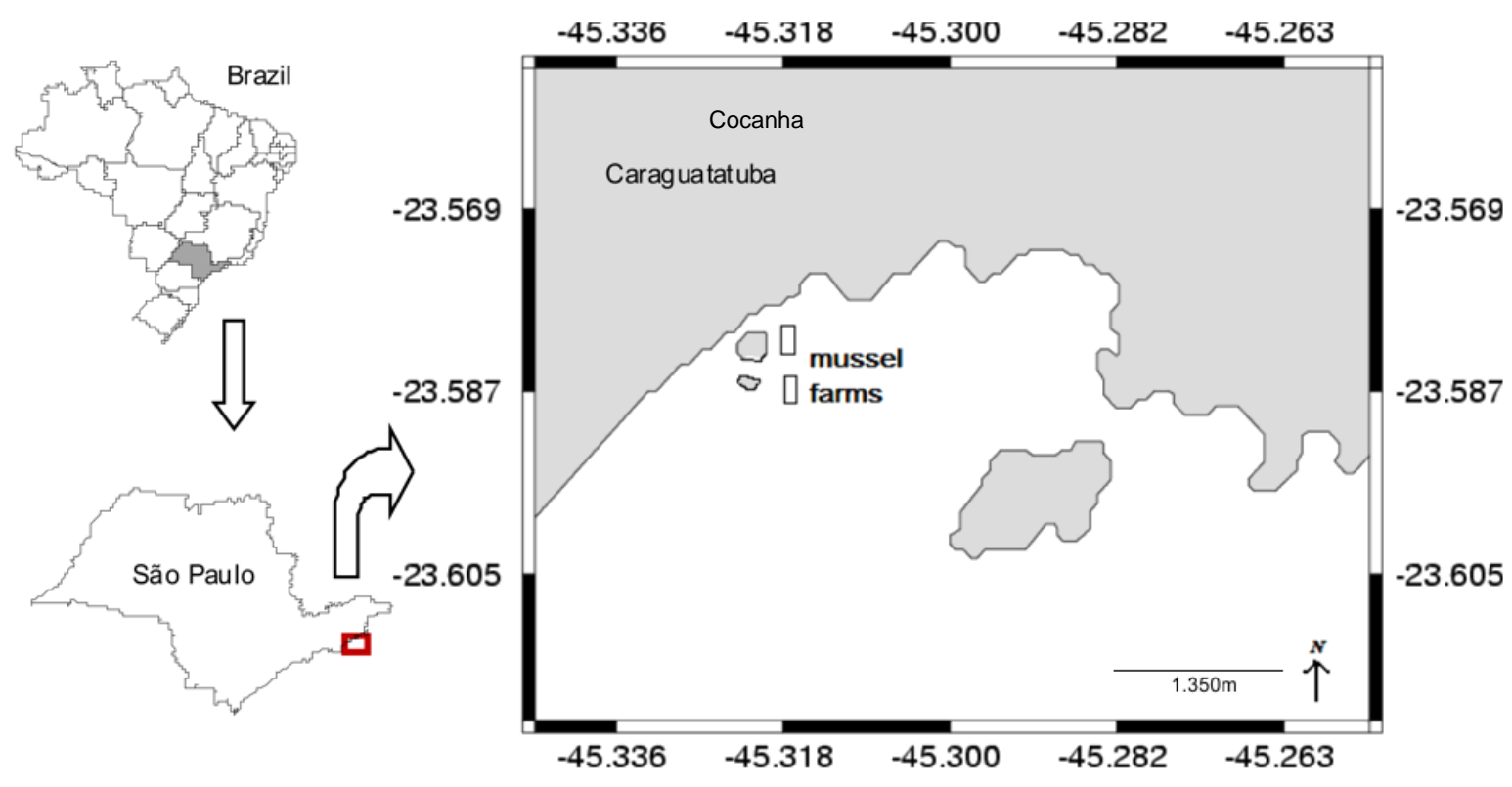

Figure 1 - Location of the study area, Praia da Cocanha, Caraguatatuba, São Paulo, Brazil.

Mussels have been reared since 1988 , by hand, on the ropes about $2.0 \mathrm{~m}$ long suspended from $50-\mathrm{m}$ long-lines (Silvestri et al. 2008a). The mussels are usually seeded between April and May, when the seeds (young mussels) are placed in growing structures. The harvest is done by removing the ropes and dropping the mussels, which are then washed with water and cleaned of fouling organisms. The mussels are harvested when they reach the proper market length, which in the study 
area varies between 7-8 $\mathrm{cm}$ and is reached after 89 months of rearing, in January and February (Marques 1998).

The northern coast of São Paulo is an oligomesotrophic region, influenced by seasonal upwelling (Miranda 1982; Aidar et al. 1993; Castro-Filho and Miranda 1998). The farms are located at depths from 5-10 m, and are mainly influenced by longshore NE currents in the summer, with weak currents and winds. Strong SW currents occur in autumn / winter (Tessler 1998) and provide a wide variability in water composition and availability of larvae, which may originate from different regions of the coast in different seasons.

\section{MATERIAL AND METHODS}

Four quarterly samples were taken in May, August, and November 2007 and February 2008. On each occasion, nine mussel ropes were randomly selected and removed from the water in bag nets especially developed to prevent the escape of organisms. Later, on a mussel cleaning table, the biological material was sorted and preserved. The specimens of Brachyura and Anomura were separated and identified according to Melo (1996). Similarly, for each rope, 30 mussels were randomly selected to determine the total shell length (mm).

To evaluate the composition and seasonal variation on the mussel ropes, the following community descriptors (Rodrigues 2005) were determined for each sample: abundance $(\mathrm{N})$, dominance of Berger-Parker (d), first-order Jackknife species richness (ED), Shannon-Wiener Diversity Index $\left(\mathrm{H}^{\prime}\right)$, and Pielou evenness (J). These descriptors were compared between the sampling periods with one-way ANOVAs followed by the SNK Test for a posteriori multiple comparisons (Underwood 1997), for the 9 replicates (ropes) sampled quarterly. For comparison of the community as a whole between different periods of the year, one-way ANOSIM (Clarke and Warwick 2001) was used with 999 permutations, Bray-Curtis similarity index, and non-standardized data. The results were expressed graphically through an ordination analysis (Nonmetric Multidimensional Scaling - NMDS) (Clarke and Warwick 2001).

\section{RESULTS}

The presence of crustaceans was recorded on all the mussel ropes sampled. In all, 1,208 individuals were identified, comprising five families and 28 species (Table 1). Most organisms identified during the study period belonged to the family Xanthidae, with a total of 16 species, comprising $62.8 \%$ of the individuals (Fig. 2). The most numerous species was the porcellanid Pachycheles laevidactylus (18.5\%), followed by the xanthids Acantholobulus schmitti (16.6\%), Hexapanopeus paulensis (11.3\%), Panopeus americanus (10.2\%), and Menippe nodifrons (8.4\%) (Table 1).

These values were not constant during the year; Acantholobulus schmitti was more abundant (40.2\%) in May, and Hexapanopeus paulensis $(29.6 \%)$ in August 2007. However, in November 2007 and February 2008, the porcellanid Pachycheles laevidactylus was the most abundant species, with $26.3 \%$ and $22.0 \%$, respectively.

The xanthids Hexapanopeus paulensis, Acantholobulus schmitti, Menippe nodifrons, Panopeus americanus, Panopeus austrobesus, Panopeus occidentalis, Pilumnus dasypodus, Pilumnus reticulatus, and Pilumnus spinosissimus, the grapsid Pachygrapsus transversus, and the porcellanid Pisidia brasiliensis were recorded in all the sampling months (Table 1). The exotic Indo-Pacific crab Charybdis hellerii was also recorded in all the months, but mainly in November and February, comprising $7.9 \%$ of the total fauna identified. Eurypanopeus abbreviatus and Portunus rufiremus were recorded only in May 2007, Mycrophrys bicornutus only in August 2007, and Panopeus bermudensis, Petrolisthes galathinus, and Callinectes sp. only in February 2008 (Table 1). 
Table 1 - Occurrence of Brachyuran and Anomuran species attached to mussel ropes at Praia da Cocanha, Caraguatatuba, São Paulo, Brazil, from May 2007 through February 2008.

\begin{tabular}{|c|c|c|c|c|c|c|c|c|}
\hline Infraorder & Family & Species & May & August & November & February & $\mathbf{N}$ & $\%$ \\
\hline \multirow[t]{22}{*}{ Brachyura } & Portunidae & Cronius ruber (Lamarck, 1818) & 3 & & & 2 & 5 & 0,4 \\
\hline & & Portunus rufiremus Holthuis, 1959 & 2 & & & & 2 & 0,2 \\
\hline & & Callinectes sp. & & & & 1 & 1 & 0,1 \\
\hline & & Charybdis hellerii A. Milne Edwards, 1867 & 3 & 1 & 41 & 50 & 95 & 7,9 \\
\hline & Xanthidae & Eurypanopeus abbreviatus (Stimpson, 1860) & 1 & & & & 1 & 0,1 \\
\hline & & Hexapanopeus sp. & & & & 28 & 28 & 2,3 \\
\hline & & Hexapanopeus paulensis Rathbun, 1930 & 11 & 50 & 27 & 48 & 136 & 11,3 \\
\hline & & Acantholobulus schmitti Rathbun, 1930 & 43 & 24 & 76 & 58 & 201 & 16,6 \\
\hline & & Menippe nodifrons Stimpson, 1859 & 11 & 8 & 22 & 61 & 102 & 8,4 \\
\hline & & Panopeus americanus Saussure, 1857 & 13 & 36 & 50 & 24 & 123 & 10,2 \\
\hline & & Panopeus austrobesus Williams, 1983 & 1 & 2 & 4 & 3 & 10 & 0,8 \\
\hline & & Panopeus sp. & 1 & & 2 & 43 & 46 & 3,8 \\
\hline & & Panopeus occidentalis Saussure, 1857 & 1 & 3 & 4 & 8 & 16 & 1,3 \\
\hline & & $\begin{array}{l}\text { Panopeus bermudensis Benedict \& Rathbun, } \\
1891\end{array}$ & & & & 3 & 3 & 0,2 \\
\hline & & Pilumnus dasypodus Kingsley, 1879 & 6 & 8 & 7 & 3 & 24 & 2,0 \\
\hline & & Pilimnus diomedeae Rathbun, 1894 & 1 & & 1 & & 2 & 0,2 \\
\hline & & Pilumnus reticulatus Stimpson, 1860 & 4 & 3 & 3 & 9 & 19 & 1,6 \\
\hline & & Pilumnus sp. & & & & & 3 & 0,2 \\
\hline & & Pilumnus spinosissimus Rathbun, 1898 & 1 & 26 & 6 & 10 & 43 & 3,6 \\
\hline & & Pilumnoides hassleri A. Milne Edwards, 1880 & 1 & & 1 & & 2 & 0,2 \\
\hline & Majidae & Microphrys bicornutus (Latreille, 1825) & & 1 & & & 1 & 0,1 \\
\hline & Grapsidae & Pachygrapsus transversus (Gibbes, 1850) & 1 & 1 & 10 & 7 & 19 & 1,6 \\
\hline \multirow[t]{6}{*}{ Anomura } & Porcellanidae & Pachycheles laevidactilus Ortmann, 1892 & & 2 & 98 & 123 & 223 & 18,5 \\
\hline & & Pachycheles monilifer (Dana, 1852) & & & 5 & 12 & 17 & 1,4 \\
\hline & & Porcellana sayana (Leach, 1820) & 2 & & 8 & 45 & 55 & 4,6 \\
\hline & & Petrolisthes armatus (Gibbes, 1850) & & & 1 & 1 & 2 & 0,2 \\
\hline & & Petrolisthes galathinus (Bosc, 1802) & & & & 1 & 1 & 0,1 \\
\hline & & $\begin{array}{l}\text { Pisidia brasiliensis Haing in Rodrigues da } \\
\text { Costa, } 1968\end{array}$ & 1 & 4 & 4 & 19 & 28 & 2,3 \\
\hline Total & & & 107 & 169 & 373 & 559 & 1208 & 100,0 \\
\hline
\end{tabular}

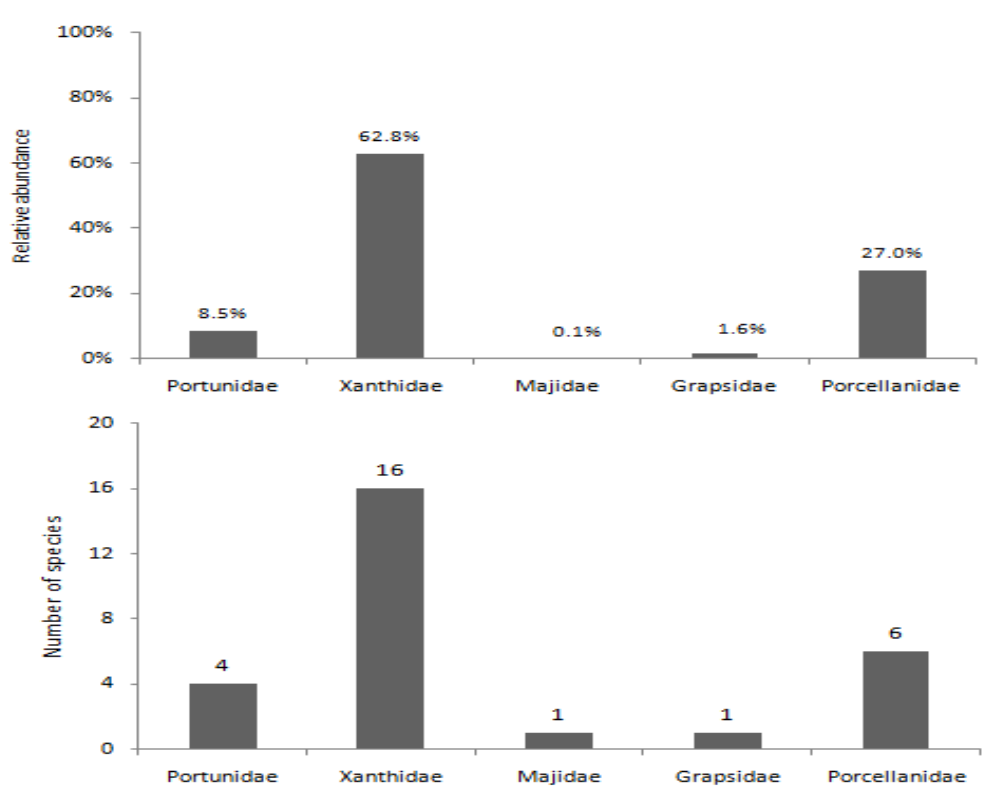

Figure 2 - Relative abundance $(\%, \mathrm{n}=1208)$ and species richness related to the families of brachyuran and anomuran found attached to mussel ropes on the Praia da Cocanha, Caraguatatuba, São Paulo, Brazil, from May 2007 to February 2008. 
The ecological descriptors, except the Pielou evenness index, varied significantly over the time (Table 2). The highest values were recorded in November and February for the abundance (41.4 \pm 7.9 and $62.1 \pm 12.3$ individuals per rope), richness (9.2 \pm 0.7 and $10.7 \pm 1.0$ species per rope), and Shannon Diversity Index $(0.80 \pm 0.04$ and 0.86 \pm 0.04 ) (Fig. 3). The lowest recorded abundance (11.9 \pm 2.9 and $18.8 \pm 5.0$ individuals per rope), richness (5.0 \pm 0.6 and $5.4 \pm 0.9$ species per rope), and diversity $(0.58 \pm 0.04$ and $0.57 \pm 0.09)$ occurred in May and August respectively. For the BergerParker dominance the pattern was reversed, and the lowest values $(0.27 \pm 0.03)$ were recorded in February (Fig. 3).
The total length of the mussels on the ropes also varied significantly between the months (Table 2), $49.4 \pm 3.4$ to $71.5 \pm 0.90 \mathrm{~mm}$, with the individuals in May being significantly smaller than in August, which in turn were significantly smaller than those in November and February $(\mathrm{M}<\mathrm{A}<\mathrm{N}=\mathrm{F})$ (Fig. 3).

The ANOSIM revealed significant differences in assemblage structure over time (Global $\mathrm{R}=0381$, $\mathrm{p}<0.001$ ), with May and August having similar compositions $(\mathrm{R}=0107, \mathrm{p}=0.052)$, but differing from the other months ( $p<0.05$ for all comparisons). November and February showed a marginal difference $(\mathrm{R}=0167, \mathrm{p}=0.043)$ (Fig. 4).
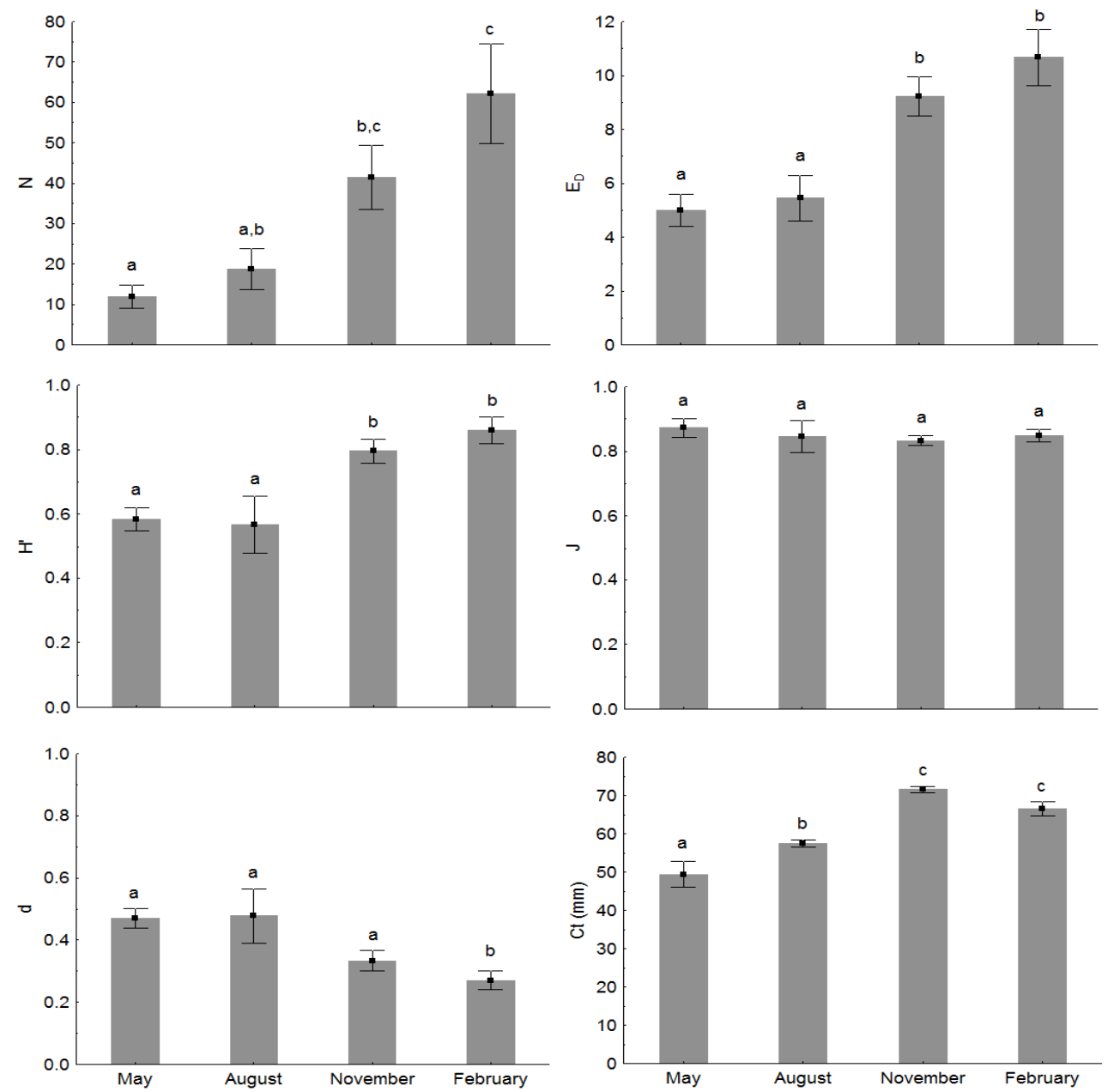

Figure 3 - Monthly means ( \pm standard error) for the descriptors Abundance $(\mathrm{N})$, first-order Jackknife Species Richness (ED), Shannon-Wiener diversity index (H '), Pielou evenness (J), and Berger-Parker dominance (d), referring to the brachyuran and anomuran fauna attached to mussel ropes, and mussel mean length $(\mathrm{mm}, \mathrm{n}=30)$ at Praia da Cocanha, Caraguatatuba, São Paulo, Brazil, from May 2007 through February 2008. 
Table 2 - One-way ANOVA (F) for the abundance (N), first-order Species Richness Jackknife (ED) ShannonWiener (H '), Pielou evenness (J), and Dominance of Berger-Parker (d) for the brachyuran and anomuran fauna attached to mussel ropes, and mussel mean length $(\mathrm{mm}, \mathrm{n}=30)$ at Praia da Cocanha, Caraguatatuba, São Paulo, Brazil, from May 2007 through February 2008.

\begin{tabular}{|c|c|c|c|c|}
\hline Source of variation & Df & Ms & $\mathbf{F}$ & $\mathbf{p}$ \\
\hline \multicolumn{5}{|l|}{ Abundance $(N)$} \\
\hline intercept & 1 & 40535.11 & 72.670 & $<0.001$ \\
\hline month & 3 & 4696.44 & 8.419 & $<0.001$ \\
\hline error & 32 & 557.80 & & \\
\hline \multicolumn{5}{|l|}{ Jackknife richness $\left(E_{D}\right)$} \\
\hline intercept & 1 & 2070.25 & 341.876 & $<0.001$ \\
\hline month & 3 & 70.32 & 11.613 & $<0.001$ \\
\hline error & 32 & 6.06 & & \\
\hline \multicolumn{5}{|l|}{ Shannon diversity $\left(H^{\prime}\right)$} \\
\hline intercept & 1 & 17.73 & 648.566 & $<0.001$ \\
\hline month & 3 & 0.19 & 7.142 & $<0.001$ \\
\hline error & 32 & 0.03 & & \\
\hline \multicolumn{5}{|l|}{ Eveness $(J)$} \\
\hline intercept & 1 & 25.23 & 3211.158 & $<0.001$ \\
\hline month & 3 & 0.00 & 0.312 & 0.817 \\
\hline error & 31 & 0.01 & & \\
\hline \multicolumn{5}{|l|}{ Berger-Parker dominance } \\
\hline intercept & 1 & 5.42 & 227.323 & $<0.001$ \\
\hline month & 3 & 0.10 & 3.964 & 0.016 \\
\hline error & 32 & 0.02 & & \\
\hline \multicolumn{5}{|l|}{ Total length $(C t)$} \\
\hline intercept & 1 & 134872.56 & 3607.284 & $<0.001$ \\
\hline month & 3 & 865.43 & 23.147 & $<0.001$ \\
\hline error & 32 & 37.39 & & \\
\hline
\end{tabular}

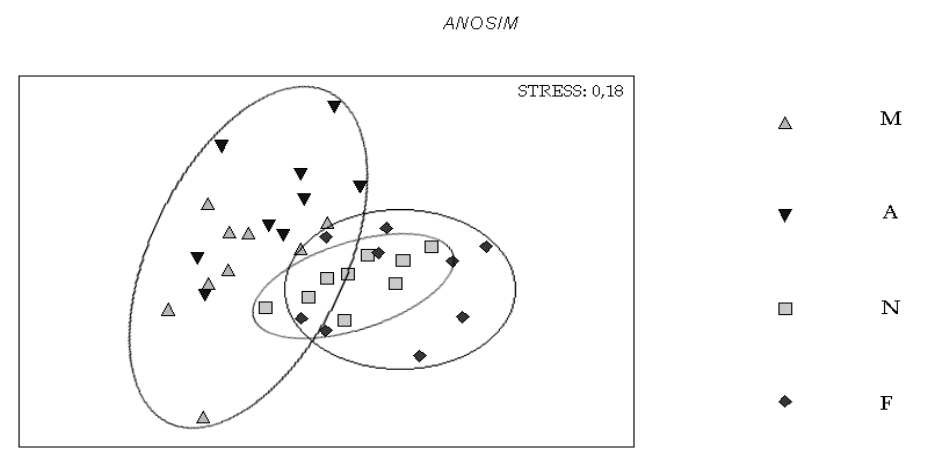

Figure 4 - MDS representing the result of one-way ANOSIM comparing the composition of species of Brachyura and Anomura attached to mussel ropes at Praia da Cocanha, Caraguatatuba, São Paulo, Brazil, from May 2007 through February 2008, at various periods of the year (M, May; A, August; N, November; and F, February). The ellipses represent the periods between which the community structure showed no significant differences $(M=N \neq A \neq F)$.

\section{DISCUSSION}

Other studies have also reported the presence of crabs in mussel farms, indicating that they can provide favorable conditions for development of these organisms (Freitas 1997; Marenzi and Branco 2006; Sá et al. 2007). These studies also reported the presence of xanthid, grapsid, and porcellanid crabs, although in relatively lower numbers than found in this study. Sá et al. (2007) 
reported the presence of two species of brachyurans in Espírito Santo, and Freitas (1997) and Marenzi and Branco (2006) recorded one family of anomuran and two families of brachyurans from mussel farms in Santa Catarina.

The most numerous species, the anomuran Pachycheles laevidactylus and the brachyuran Acantholobulus schmitti, are distributed along the entire Brazilian coast. P. laevidactylus is often found among rocks, clumps of algae, and mussel beds (Melo 1999), and A. schmitti is found from the intertidal zone up to 25 meters deep, on sand bottom, mud, and shell bottoms (Melo 1996); i.e., the life habits of these species favor their occupation of mussel ropes. The portunid Portunus rufiremus was observed below its southern distribution limit (Melo 1996), which could be the result of larval dispersal along the coast or of larval transport by ballast water (Tavares and Mendonça Jr. 2004), considering that the study area was located about $26 \mathrm{~km}$ from the Port of São Sebastião.

The presence of Charybdis hellerii has been reported in other studies in the region (Mantelatto and Fransozo 2000, Bertini et al. 2004; Bertini and Fransozo 2004; Braga et al. 2005). However, the high absolute and relative abundance of $C$. hellerii, mainly small-sized individuals, observed in this study indicates that the ropes can be important refuges for this invasive species, and also sources of dispersal to other areas.

The availability of food is a major factor in colonization of crustaceans in marine farms. The great diversity of amphipods, algae, polychaetes, and gastropods associated with mussel ropes at the study site (Silvestri et al. 2008b) ensures a good food source for crabs (Freire and GonzálezGurriarán 1995; Petti et al. 1996; Frigotto and Seraphim-Junior 2008; Santana et al. 2009). Crabs act as natural control agents of fouling organisms, helping to maintain the cleanliness of mussel ropes to the market (Mallet et al. 2009), thus avoiding the costs of removing the fouling, which can reach up to $20 \%$ of the final product (Enright et al. 1993).

Conversely, larvae and seed mussels also represent an important food source for these crustaceans. Some studies indicate the existence of predatory crustaceans in different types of bivalve culture (Seed 1976; Waterstrat et al. 1980; Freites et al. 2000; DeGraaf and Tyrrell 2004), thus also constituting a problem for the farms.
The significant differences found in the community structure of crabs during the study period could be related to the long immersion time of the ropes (8-9 months), because with longer immersion times, the community tended to develop and gain complexity. In fact the abundance, richness, and diversity increased as the total length of the mussels increased, with a peak in November and February (Fig. 3). Mallet et al. (2009), in a study conducted at Prince Edward Island, Canada, reported a decline in the abundance of the crab Cancer irroratus in a farm of mussels Mytilus edulis from spring to autumn, which could be attributed to the seasonal migration and fisheries targeting this species.

The colonization by the crabs in mussel farms benefits from their pelagic larvae, which disperse easily and locate substrates favorable for settling in the mussel farms. Although seasonality is less pronounced than in temperate or subtropical areas, populations of decapod crustaceans in nearby areas show significant variations in their reproductive periods (Turra and Leite 2000), which can regulate the supply of larvae and recruits in farms. However, it is evident that the structures used in mussel farms provide conditions conducive to colonization by these crustaceans.

The results described above indicated the potential use of the crustaceans associated with mussel ropes in interdisciplinary studies, such as those related to livestock productivity (predation of mussels and biocontrol of fouling) or environmental monitoring, using species that indicated environmental quality. The high diversity and quantity of epibionts recorded suggested an opportunity to add value to artisanal farms, since the crustaceans could have value in the aquarium trade.

\section{ACKNOWLEDGEMENTS}

The authors acknowledge the collaboration of Gustavo Augusto Schmidt de Melo and Marcos Tavares of the Museum of Zoology, University of Sao Paulo in confirming the identification of species recorded; and of the shellfisherman José Luiz Alves, the Fisheries and Shellfishermen Association of Praia da Cocanha - MAPEC, and Aquaculture Engineer Thiago Cabral Vilar for their help during field and laboratory work. 
FINANCIAL SUPPORT: FAPESP (Scholarship grant to FS), CNPq (Productivity grant to AT), and PADI FOUNDATION.

\section{REFERENCES}

Aidar E, Gaeta SA, Gianesella-Galvão S, Kutner MBB, Teixeira C. Ecossistema costeiro subtropical: nutrientes dissolvidos, fitoplâncton, clorofila a e suas relações com as condições oceanográficas na região de Ubatuba, SP. São Paulo. Publ. Espec. Inst. Oceanogr. 1993; 10: 9-43.

Amaral ACZ, Jablonski S. Conservação da Biodiversidade Marinha e Costeira no Brasil. Megadiversidade. 2005; 1(1): 43-51.

Bayne BL. Marine Mussels: Their Ecology and Physiology. Cambridge: Cambridge University Press; 1976.

Bertini G, Fransozo A. Bathymetric distribution of brachyuran crab (Crustacea, Decapoda) communities on coastal soft bottoms off southeastern Brazil. Mar. Ecol. Prog. Ser. 2004; 279: 193-200.

Bertini G, Fransozo A, Melo GAS. Biodiversity of brachyuran crabs (Crustacea: Decapoda) from nonconsolided sublitoral bottom on the northern coast of São Paulo State, Brazil. Biodiversity Conserv. 2004; 13: 2185-2207.

Braga AA, Franzoso A, Bertini G, Funis PB. Composição e abundância dos caranguejos (Decapoda, Brachyura) nas regiões de Ubatuba e Caraguatatuba, litoral norte paulista, Brasil. Biota Neotropica. 2005; 5(2): 45-78.

Carvalho YBM. Macrofauna associada ao cultivo suspenso de vieiras Nodipecten nodosus (L.) localizado na Ilha Grande, Angra dos Reis, Rio de Janeiro (Monografia). São Vicente: Universidade Estadual Paulista Júlio de Mesquita Filho; 2007.

Castro-Filho BM, Miranda LB. Physical oceanography of the Western Atlantic continental shelf located between $4^{\circ} \mathrm{N}$ and $34^{\circ} \mathrm{S}$. In: Robinson AR, Kenneth HB. (orgs). The Sea, The Global Coastal Ocean. New York: 1998; 209-251.

Clarke KR, Warwick RM. Change in Marine Communities: An Approach to Statistical Analysis and Interpretation. 2nd ed. Plymouth, UK: PRIMERE Ltd; 2001.

Degraaf JD, Tyrrell MC. Comparison of the feeding rates of two introduced crab species, Carcinus maenas and Hemigrapsus sanguineus, on the blue mussel, Mytilus edilus. Northeast. Nat. 2004; 11(2): 163-166.

Enright CT, Elner RW, Griwold A, Borgese EM. Evaluation of crabs as control agents for biofouling in suspended culture of European oysters. World Aquac. 1993; 24: 49-51.
Freire J, González-Gurriarán E. Feeding ecology of the velvet swimming crab Necora puber in mussel raft areas of the Ría de Arousa (Galicia, NW Spain). Mar. Ecol. Prog. Ser. 1995; 119; 139-154.

Freitas M. Incrustações biológicas no mexilhão Perna perna (Mollusca, Bivalvia) cultivado na Ilha de Ratones, SC: efeito da exposição ao ar (Dissertação de Mestrado). Florianópolis: Universidade Federal de Santa Catarina; 1997.

Freites L, Himmelmam JH, Lodeiros CJ. Impact of predation by gastropods and crabs recruiting into culture enclosures on the survival of the scallop Euvola ziczac (L.) in suspended culture. J. Exp. Mar. Biol. Ecol. 2000; 244(2): 297-303.

Frigotto SF, Serafim-Junior M. Ocorrência de Crustacea (Decapoda) em cultivos de ostra na Baía de Guaratuba. In: XXVII Congresso Brasileiro de Zoologia. Proceedings: Contributed papers-abstract; 2008 Feb; Curitiba, Paraná. Curitiba: Sociedade Brasileira de Zoologia: SBZ: 2008.

González-Gurriarán E. Seasonal changes of benthic megafauna in the Ría de Muros e Noia (Galicia, North-West Spain) II. Decapod Crustaceans (Brachyura). Mar. Biol. 1986; 92: 201-210.

Leite LA. Influência da predação, parasitismo e densidade de sementes nas perdas de mexilhões Perna perna (L., 1758), cultivados na Baía Norte da Ilha de Santa Catarina (Dissertação de Mestrado). Florianópolis: Universidade Federal de Santa Catarina; 2007.

Mallet JF, Leblanc AR, Ouellette M, Comeau LA. Abundance and function of rock crabs (Cancer irroratus) in longline mussel (Mytilus edulis) farms. Can. Tech. Rep. Fish. Aquat. Sci. 2862; 2009; 1-53.

Mantelatto FLM, Fransozo A. Brachyuran community in Ubatuba Bay, Northern Coast of São Paulo State, Brazil. J. Shellfish Res. 2000; 19(2): 701-709.

Marenzi AWC, Branco JO. O cultivo do mexilhão Perna perna no município de Penha, SC. In: Branco JO, Marenzi AWC. (Org.). Bases Ecológicas para um Desenvolvimento Sustentável: Estudos de Caso em Penha, SC. Itajaí, SC: Editora da UNIVALI; 2006; 227-244.

Marenzi AC, Manzoni GCM. Cultivo de moluscos marinhos: Estabelecimento de novo ecossistema em regiões costeiras de Santa Catarina. In: IV Simpósio de Ecossistemas Brasileiros. Proceedings: Contributed papers-abstract; 1998 Mar; Águas de Lindóia, 1998; 3: 438-442.

Marques HLA. Criação Comercial de Mexilhões. São Paulo: Nobel. 1998; 62-63.

Melo GAS. Manual de Identificação dos Brachyura (Caranguejos e Siris) do Litoral Brasileiro. São Paulo: Ed. Plêiade/FAPESP. 1996.

Melo GAS. Manual de Identificação dos Crustácea Decapoda do Litoral Brasileiro. São Paulo: Ed. Plêiade/FAPESP. 1999. 
Metri R, Rocha RM, Marenzi A. Epibiosis reduction on productivity in a mussel culture of Perna perna (Linné, 1758). Braz. Arch. Biol. Tech. 2002; 45(3): 325-31.

Miranda LB. Análise de massas de água da plataforma continental e da região oceânica adjacente: Cabo de São Thomé (RJ) à Ilha de São Sebastião (SP) (Tese de livre-docência). São Paulo: Instituto Oceanográfico, Universidade de São Paulo; 1982.

Muiño R. Fecundity of Liocarcinus depurator (Brachyura: Portunidae) in the Ría de Arousa (Galicia, north-west Spain). J. Mar. Biol. Ass. U.K, 2002; 82(1): 109-116.

Petti MAV, Nonato EF, Paiva PC. Trophic relationships between polychaetes and brachyuran crabs on the southeastern Brazilian coast. Rev. Bras. Oceanogr. 1996; 44(1): 61-67.

Rodrigues WC. DivEs - Diversidade de Espécies. Versão 2.0 Software e Guia do Usuário; 2005 (cited 2009 Nov. 22); Available from: http://www.ebras.bio.br/dives>.

Romero P, González-Gurriarán E, Penas E. Influence of mussel rafts on spatial and seasonal abundance of crabs in the Ría de Arousa, North-West Spain. Mar. Biol. 1982; 72: 201-210.

Sá FS, Nalesso RC, Paresque K. Fouling organisms on Perna perna mussels: is it worth removing them? Braz. J. Oceanogr. 2007; 55(2): 155-161.

Sampedro MP, Fernández L, Freire J, GonzálezGurriarán E. Fecundity and Reproductive Output of Pisidia longicornis (Decapoda, Anomura) in the Ría de Arousa (Galicia, NW Spain). Crustaceana. 1997; 70(1): 95-110.

Santana GX, Fonteles-Filho AA, Bezerra LEA, Matthews-Cascon H. Comportamento Predatório Ex situ do Caranguejo Menippe nodifrons Stimpson, 1859 (Decapoda, Brachyura) sobre Moluscos Gastrópodes. PanamJAS. 2009; 4(3): 326-338.

Seed R. Ecology. In: Marine Mussels: Their Ecology and Physiology. Bayne, B. L (Ed.). Cambridge: Cambridge University Press; 1976.

Silvestri F, Bordon ICAC, Bueno RS, Turra A, Marques HLA. Cultivo de bivalvos en el estado de San Pablo, Brasil. Infopesca Internacional; 2008a; 35: 36-39.

Silvestri F, Vilar TC, Rodrigues CW, Turra A. Organismos associados ao cultivo de mexilhões na Praia da Cocanha, Caraguatatuba, São Paulo. In:
XXVII Congresso Brasileiro de Zoologia. Proceedings: Contributed papers-abstract; 2008 Fev; Curitiba, Paraná. Curitiba: Sociedade Brasileira de Zoologia: SBZ: 2008a.

Sinau. Sistema Nacional de Informações das Autorizações de Uso das Águas da União para Fins de Aqüicultura. Ministério da Pesca e Aqüicultura/MPA. 2009. (cited 2009 Dec. 15) Available from: http://200.198.202.145/seap/sinau_web/html2/index_i ntro.html>.

Tavares M, Mendonça Jr JB, Silva J, Souza R. Introdução de crustáceos exóticos no Brasil: uma roleta ecológica. In: Silva and Souza. Água de Lastro e Bioinvasão. Rio de Janeiro. Interciência, 2004; 5976.

Tessler MG. Dinâmica sedimentar quaternária no Litoral Sul Paulista (Tese de doutorado). São Paulo: Instituto de Geociências, Universidade de São Paulo; 1988.

Turra A, Leite FPP. Population biology and growth of three sympatric species of intertidal hermit crabs in southeastern Brazil. J. Mar. Biol. Ass. U.K. 2000; 80: 1061-1069.

Underwood AJ. Experiments in Ecology: Their Logical Design and Interpretation Using Analyses of Variance. Cambridge: Cambridge University Press; 1997.

Uribe E, Lodeiros C, Félix-Pico C, Etchepare I. Los moluscos pectínidos de Iberoamérica: Epibiontes en pectínidos de Iberoamérica. Maeda-Martinez AN. (ed.). Cienc. Acuicult. 2001; 13: 249-266.

Vaquero RAM. Fauna Associada ao Cultivo de Moluscos, na Armação do Itapocoroy, Penha, SC (Monografia). Itajaí, SC: Universidade do Vale do Itajaí; 2006.

Waterstrat P, Chew K, Johnson K, Battie JH. Mussel Culture: a West Coast Perspective. In: Lutz RA, Center ICD. Mussel Culture and Harvest: A North American Perspective. New York: 1980; 141-163.

Received: January 24, 2011; Revised: February 16, 2011; Accepted: April 23, 2012. 
PÁGINA

EM

BRANCO 